\title{
Ethnobotany, Pharmacology and Chemistry of Medicinal Orchids from Veracruz
}

\author{
Leticia Margarita Cano Asseleih, Rebeca Alicia Menchaca García and José Yader Sageth Ruiz Cruz \\ Centro de Investigaciones Tropicales (CITRO), Universidad Veracruzana, Xalapa 91000, Mexico
}

\begin{abstract}
Orchidaceae is a large family of 1,260 species in Mexico, of which 433 grow in the state of Veracruz, Mexico. Although economically important in horticulture because of the beauty of their flowers, researches have done little work regarding their medicinal properties. This paper aimed to present the results of ethnobotanical, pharmacological and active compounds research on Veracruz medicinal orchids. The ethnobotanical information was obtained by consulting the Atlas of the Mexican Traditional Medicine Plants, Veracruz Medicinal Flora Database (CITRO-UV project) and through field work in the Nahuatl community of Cuautlajapa, Veracruz. To obtain pharmacological and active compounds information of registered species, a search was carried out through MEDLINE (USA National Library of Medicine Journal Citation database). Twelve medicinal orchids were recorded for Veracruz, i.e., Epidendrum chlorocorymbos Schltr., Habenaria floribunda Lindl., Isochillus latibracteatus A. Rich. \& Galeotti, Isochillus major Schltdl. \& Cham., Mormodes maculata var. unicolor (Hook.) L. O. Williams, Oestlundia luteorosea (A. Rich. \& Galeotti) W. E. Higgins, Oncidium ascendens Lindl., Scaphyglottis fasciculata Hook., Sobralia macrantha Lindl., Spiranthes eriophora (Rob. \& Greenm.), Stanhopea oculata (G. Lodd.) Lindl. and Vanilla planifolia Andrews. Only two species have been investigated in terms of their pharmacology and active compounds. Also, information for another five species closely related to already identified ones was obtained. Given the relative poverty of current information on the topic, this paper demonstrates the need to further study the ethnobotanical, pharmacological and chemical aspects of the region's medicinal orchids.
\end{abstract}

Key words: Orchids, medicinal orchids, traditional medicine, Veracruz medicinal orchids.

\section{Introduction}

Orchidaceae is the largest family of the plant kingdom, comprising around 25,000-35,000 species [1, 2]. Prized for their strikingly beautiful flowers, orchids are widely distributed but grow in the tropical regions, and cloud forests favor its development [3]. In Mexico, it is the third largest family with 1,260 species [4] and 433 are found in the state of Veracruz [5]. Economically, they are very important in horticulture. Wild species, on the other hand, have been used as indicators of regions with a healthy ecosystem [6]. However, the value of the plants of this family in the role that they have played in medicine has often been overlooked [7].

The use of orchids in herbal medicine has a very long history, given that several orchids are listed in

Corresponding author: Leticia Margarita Cano Asseleih, Ph.D., research field: phytochemistry. the earliest known "Chinese Materia Medica" [8] and "Indian Ayurvedic Materia Medica" [9]. Nepal and other Asian countries, such as Indonesia, Malaysia, Taiwan, Singapore, Vietnam, Shri Lanka, Thailand, Myanmar, etc., have been using orchids in traditional medicine [10].

Use of orchids in America has a long history too. In Mexico, their use as a source of glue and resin by the Aztecs and other ethnic groups since ancient times has been of great importance [3]. Similarly, Vanilla, mainly Vanilla planifolia, was used to add aroma and flavor to cocoa and for the treatment of hysteria, fevers, impotence, rheumatism and to increase muscular energy [11]. Today, its medicinal uses are confined to strong fever and abdomen pain [12].

Although the use of medicinal orchids is spread all over the world, little information is found for the Americas as far as number of species and cultural background. In Mexico, besides Vanilla, 
documentation of some species from Yucatan was found for Catasetum intergerrimum, Cyrtopodium punctatum, Myrmecophila christinae and Rhyncholaelia digbyana (spots and wounds), Arpophyllum spicatum, Epidendrum anisatum and Bletia campanulata (dysentery) and Laelia autumnalis (cough) to treat different ailments [3]. Prosthechea karwinsky, a very valued orchid in a Mixtec community from Oaxaca, is used to treat coughs, wounds and burns, diabetes, to prevent miscarriages and to assist in childbirth [13]. Even though Veracruz is one of the most biodiverse states and houses a third of orchid species growing in Mexico, so far only two species found here have been documented in the Atlas de las Plantas de la Medicina Tradicional Mexicana [12]. They are Oncidium ascendens used for inflammation and Vanilla planifolia to treat fever and abdomen pain.

In this paper, field and bibliographical research was carried out to compile ethnobotanical, pharmacological and chemical data as far as active compounds of identified medicinal orchid species from the state of Veracruz. To link indigenous knowledge to experimental modern scientific information will help understand the effectivity of herbs and return this information to the traditional consumers, and at the same time will encourage drug development.

\section{Methodology}

Investigation of medicinal orchid species from Veracruz was carried out by consulting first the Atlas of the Mexican Traditional Medicine Plants [12], the Flora Medicinal de Veracruz [14] and the data base of Flora Medicinal de Veracruz CITRO-UV project. Field ethnobotanical research was carried out in Cuautlajapa, municipality of Mixtla de Altamirano, from Sierra de Zongolica, Veracruz, through semi-structured interviews, in situ walks and participative observation. Medicinal orchids described here were photographed, and herbarium specimens are collected and deposited in the CITRO-UV herbarium or are part of the alive collection of CITRO-UV orchidarium. Botanical identification was carried out and botanical descriptions were based on Ref. [15]. The criteria to identify orchid species included botanical identification, deposit of specimens in any herbarium of the country and specific medicinal indication. Finally, a bibliographical research of the pharmacology and chemistry (active components) of identified medicinal orchids in this work was carried out through searching of MEDLINE data base.

\section{Results and Discussion}

Results obtained through bibliographical research generated information on nine species of medicinal orchids. Field work in the Nahuatl community of Mixtla de Altamirano, Zongolica, added three more species, making a total of 12 medicinal orchids recorded for Veracruz (Fig. 1 and Table 1). For each species, a brief botanical description, ethnobotanical data, herbarium where vouchers were deposited, pharmacological and active compounds information are indicated.

All species found grow wild, except for Vanilla planifolia, which the Totonaca Indians cultivate in small areas in Northern Veracruz, mainly in the vicinity of Papantla town. And Stanhopea oculata and Mormodes maculata var. unicolor, which are part of a recently initiated sustainable use and management project carried out by the Cuautlajapa Nahuatl community, are promoted and advised by CITRO Orchids Conservation Program. Three species are terrestrial in their habitude, eight are epiphytic and one (Vanilla planifolia) is semi epiphytic.

Three of the 12 species are included in the Official Mexican Regulation NOM-SEMARNAT-059-2010 [16]. Mormodes maculata var. unicolor and Stanhopea oculata are with "threatened" status, while Vanilla planifolia are with "special protection" status. Excessive collecting from the wild (because of the beauty of their flowers) and the loss and destruction 


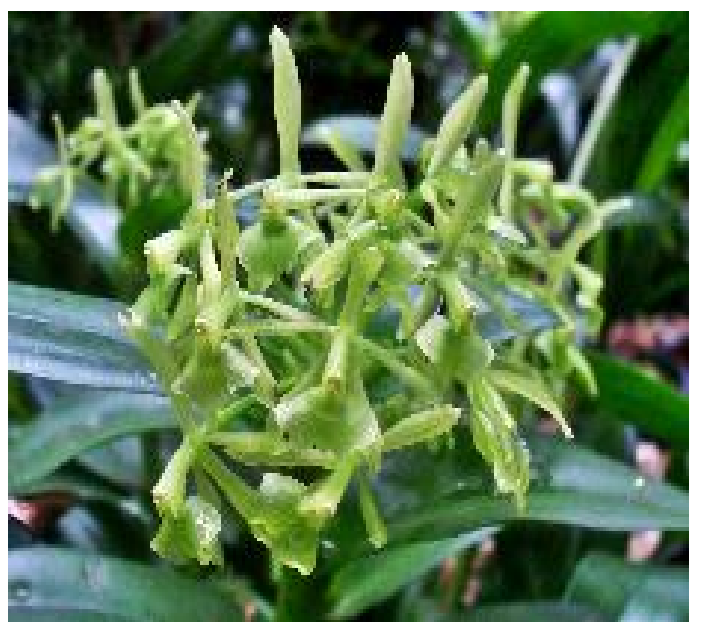

(a) Epidendrum chlorocorymbos Schltr.

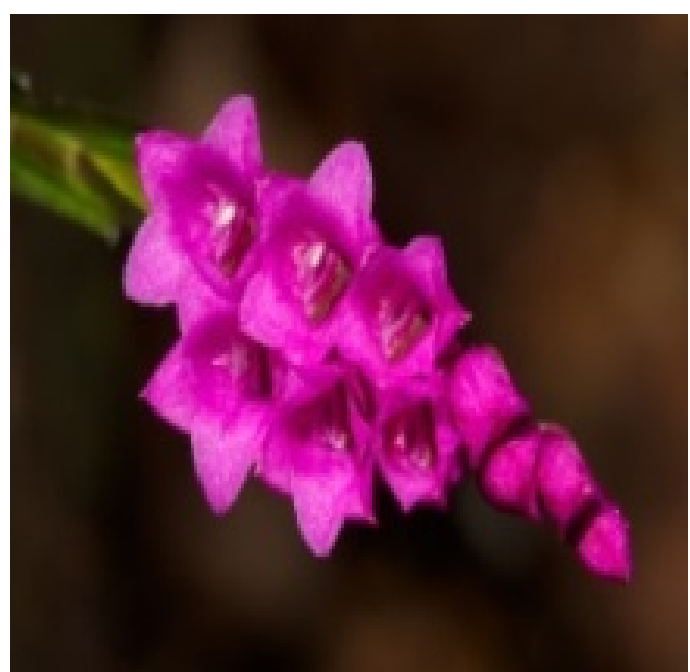

(d) Isochillus major Schltdl. \& Cham.

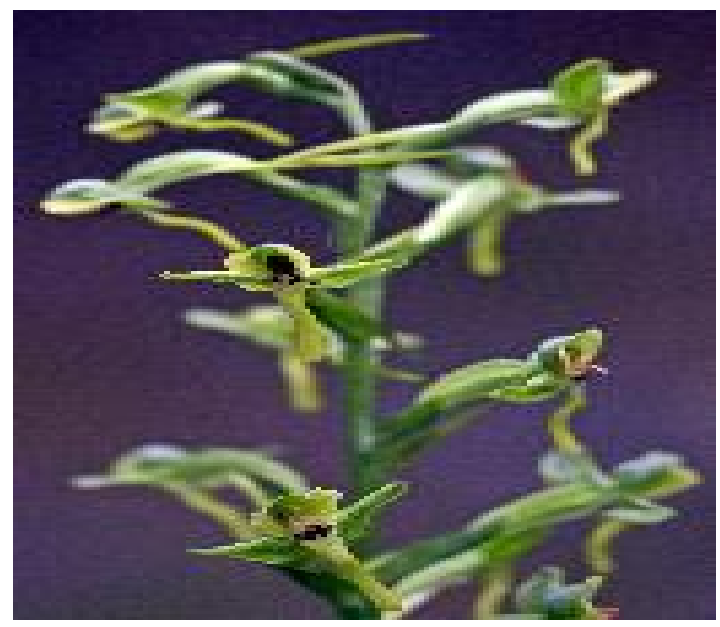

(b) Habenaria floribunda Lindl.

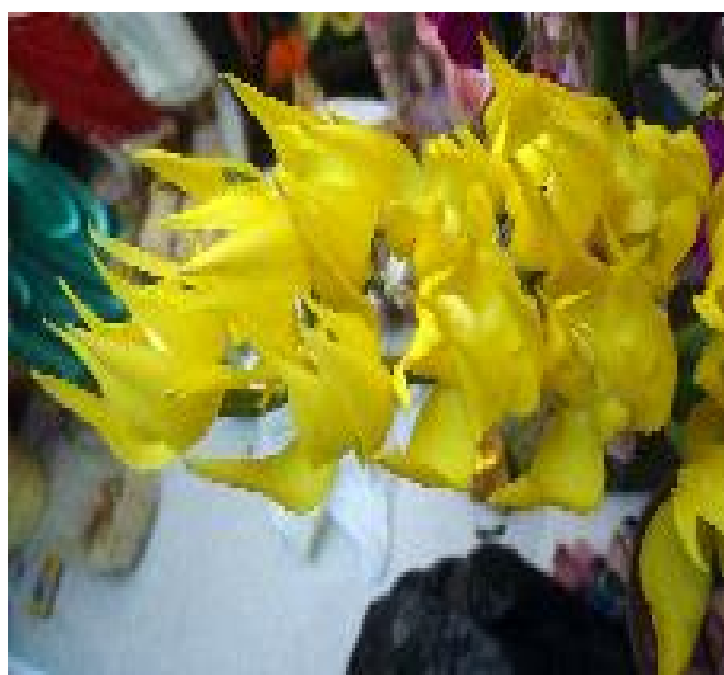

(e) Mormodes maculata var. unicolor (Hook.) L. O. Williams

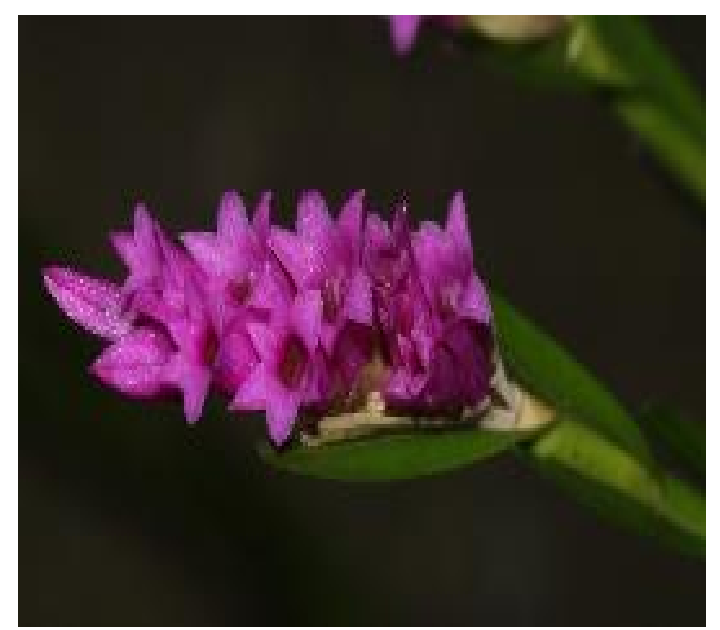

(c) Isochillus latibracteatus A. Rich. \& Galeotti

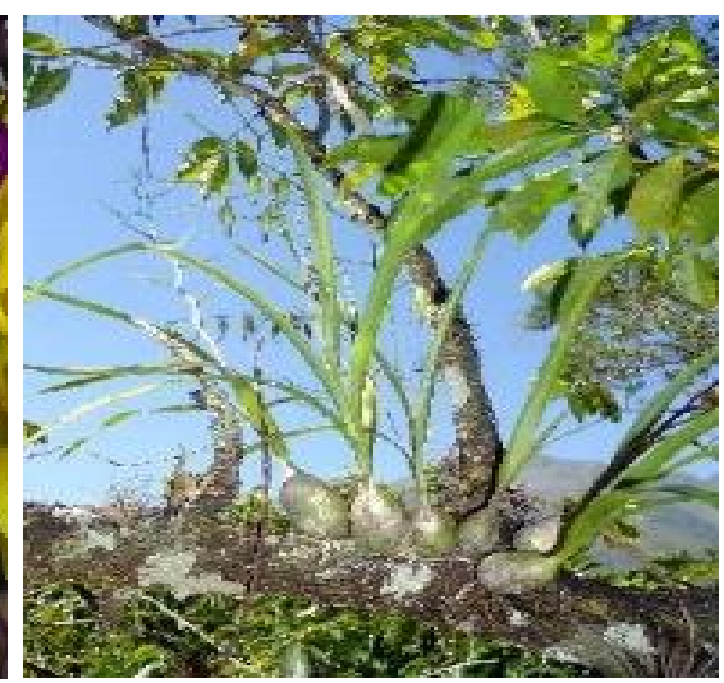

(f) Oestlundia luteorosea (A. Rich. \& Galeotti) W. E. Higgins 


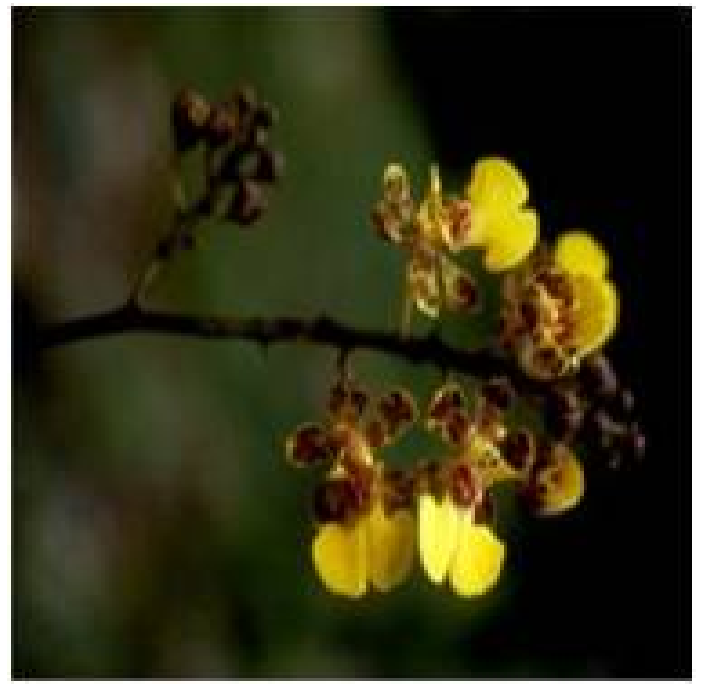

(g) Oncidium ascendens Lindl.

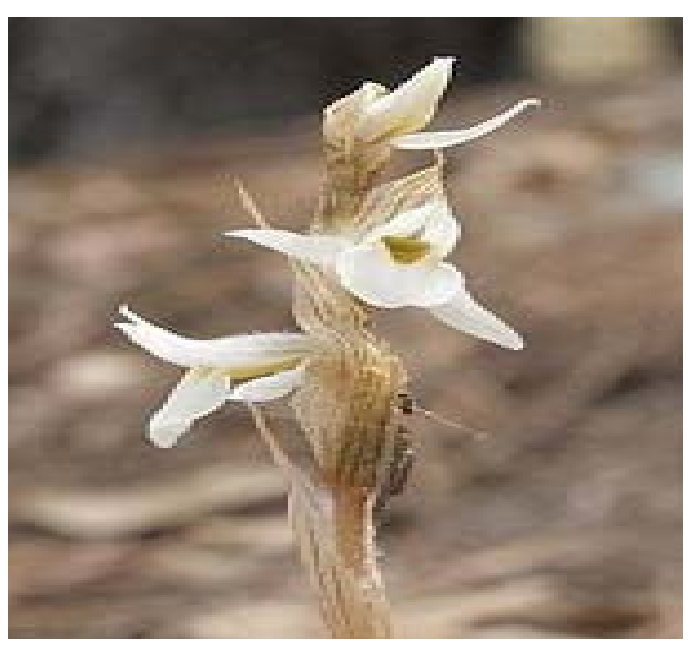

(j) Spiranthes eriophora Rob. \& Greenm.

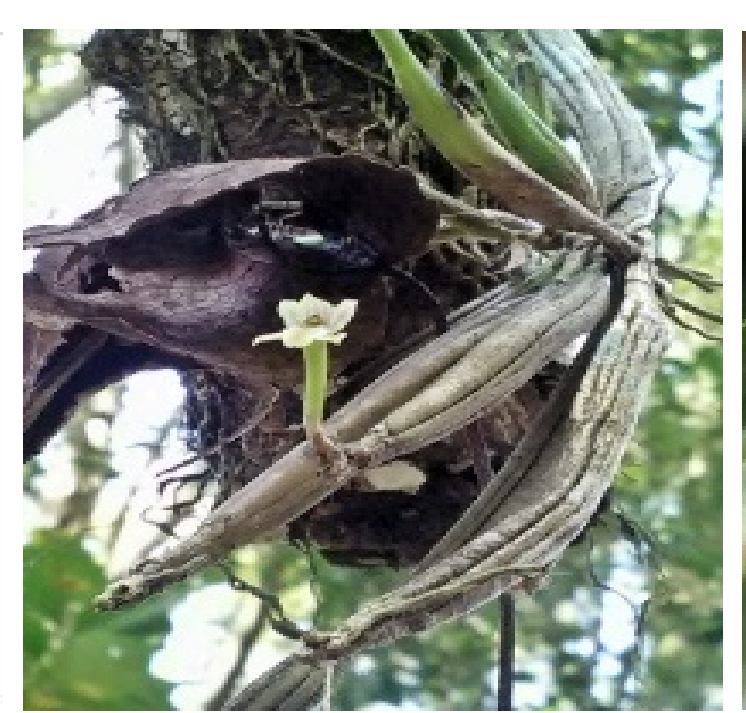

(h) Scaphyglottis fasciculata Hook.

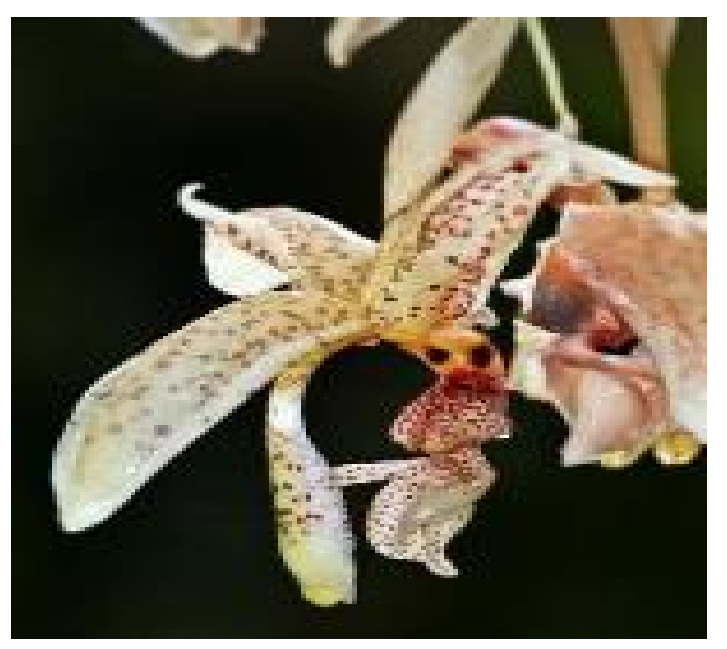

(k) Stanhopea oculata (G. Lodd.) Lindl.

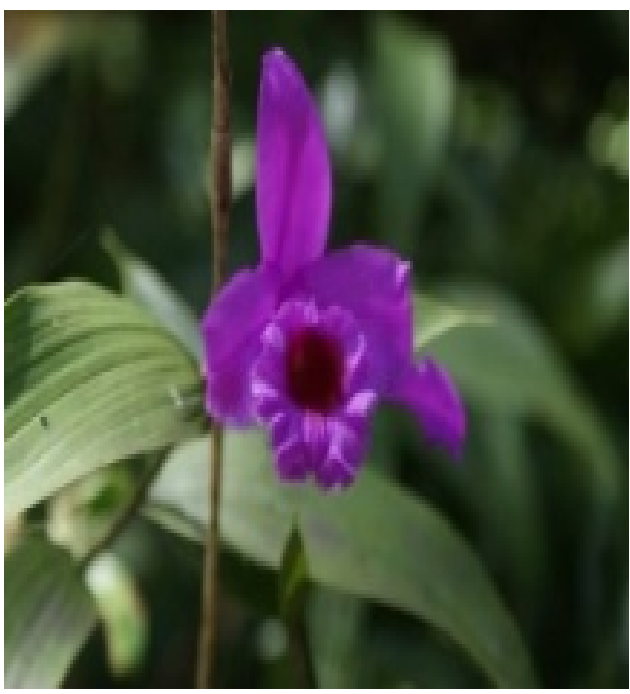

(i) Sobralia macrantha Lindl.

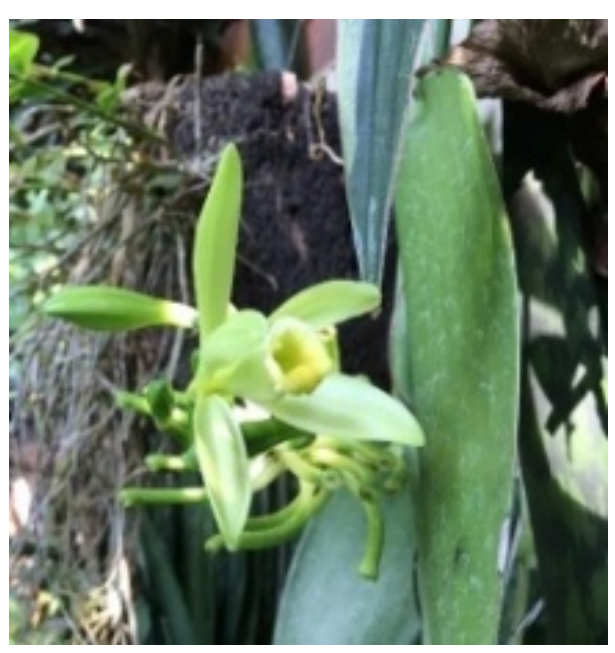

(m) Vanilla planifolia Andrews

Fig. 1 Photographs of 12 medicinal orchids from Veracruz. 
Table 1 Botanical description, ethnobotany, pharmacology and active metabolites of medicinal orchids from Veracruz.

\begin{tabular}{|c|c|c|c|c|}
\hline Orchid species & $\begin{array}{l}\text { Botanical } \\
\text { description/herbarium }\end{array}$ & Ethnobotany & Pharmacology & Active metabolites \\
\hline $\begin{array}{l}\text { Epidendrum } \\
\text { chlorocorymbos Schltr. }\end{array}$ & $\begin{array}{l}\text { Epiphyte orchid of } 15-30 \mathrm{~cm} \\
\text { high, with green to yellow } \\
\text { flowers in umbel folia } \\
\text { inflorescence. Herbarium } \\
\text { XAL. }\end{array}$ & $\begin{array}{l}\text { In Veracruz, it is known as "siempre viva" (forever alive). } \\
\text { Burgos [17] indicates that infusion of the leaves is used to } \\
\text { lower cholesterol blood levels, stimulates dreaming and } \\
\text { cure spots. It is also used for ear pain, applying few little } \\
\text { drops of the infusion. }\end{array}$ & $\begin{array}{l}\text { A strong anti-nociceptive } \\
\text { effect was found in E. } \\
\text { mosenii [18-20]. }\end{array}$ & $\begin{array}{l}\text { 24-methylene-cicloarta } \\
\text { nol, dichloromethane } \\
\text { extract [7], methanolic } \\
\text { extract [18] and } \\
\text { phenanthrenes [19-21]. }\end{array}$ \\
\hline $\begin{array}{l}\text { Habenaria floribunda } \\
\text { Lindl. }\end{array}$ & $\begin{array}{l}\text { Terrestrial orchid of } 30-85 \mathrm{~cm} \\
\text { high, with yellow green } \\
\text { flowers, in } \begin{array}{l}\text { cluster } \\
\text { inflorescence. }\end{array} \text { Herbarium } \\
\text { XAL. }\end{array}$ & $\begin{array}{l}\text { In Veracruz, it is known as "clavocochinillo" (nail piglet) } \\
\text { and it is found and used as a remedy in the region of Sierra } \\
\text { de Santa Marta in the municipality of Soteapan in the } \\
\text { localities of Ejidos de Ocotal Chico, Ocotal Grande, San } \\
\text { Fernando y Santa Martha. Santos [22] indicates the use of a } \\
\text { leaves infusion drank for vaginal hemorrhage. }\end{array}$ & $\begin{array}{l}\text { In Habenaria repens, } \\
\text { related species, } \\
\text { anti-oxidant activity has } \\
\text { been detected [23]. }\end{array}$ & $\begin{array}{l}\text { Habenariol and the } \\
\text { methanolic extract in } H \text {. } \\
\text { repens were responsible } \\
\text { of this action [23]. }\end{array}$ \\
\hline $\begin{array}{l}\text { Isochillus latibracteatus } \\
\text { A. Rich. \& Galeotti }\end{array}$ & $\begin{array}{l}\text { Epiphyte orchid of } 50 \mathrm{~cm} \text { high, } \\
\text { with purple flowers, in cluster } \\
\text { inflorescence. Herbarium } \\
\text { XAL. }\end{array}$ & $\begin{array}{l}\text { No common name was registered for this species, } \\
\text { nevertheless it is found and used as a remedy in the Sierra } \\
\text { de Santa Marta region, in the municipality of Soteapan, } \\
\text { localities of Ejidos de Ocotal Chico, Ocotal Grande, San } \\
\text { Fernando y Santa Marta. Santos [22] indicates its } \\
\text { therapeutic application for "latido" (pain in the mouth of the } \\
\text { stomach) and "ventazón" (a kind of colitis). }\end{array}$ & No information found. & No information found. \\
\hline $\begin{array}{l}\text { Isochillus major Schltdl. } \\
\text { \& Cham. }\end{array}$ & $\begin{array}{l}\text { Epiphyte orchid of } 50 \mathrm{~cm} \text { high, } \\
\text { with purple flowers and } \\
\text { unilateral and thick } \\
\text { inflorescence. Herbarium } \\
\text { CORU. }\end{array}$ & $\begin{array}{l}\text { No common name was registered for this species. It is } \\
\text { found in the municipality of Ixtaczoquitlan, the localities of } \\
\text { Cuesta del Mexicano, Tuxpanguillo, Zacatla y Zoquitlán } \\
\text { Viejo, where the leaves are used in case of blows } \\
\text { inflammation, is applied as a poultice [24]. }\end{array}$ & No information found. & No information found. \\
\hline $\begin{array}{l}\text { Mormodes maculata } \\
\text { var. unicolor (Hook.) L. } \\
\text { O. Williams }\end{array}$ & $\begin{array}{l}\text { Epiphyte orchid barely } \\
\text { terrestrial of up to } 70 \mathrm{~cm} \text {, high } \\
\text { with very brillian yellow } \\
\text { flowers arranged in basal, } \\
\text { arched and dense } \\
\text { inflorescence. Alive collection } \\
\text { in CITRO-UV Orchidarium. }\end{array}$ & $\begin{array}{l}\text { In Zongolica región, it is known as "flor de mayo" (may } \\
\text { flower) and the crushed pseudobulbs are applied as a } \\
\text { poultice to treat inflammation of affected areas of the body } \\
\text { due to abrupt movements like feet "falseadura" or twisted } \\
\text { ankle. }\end{array}$ & No information found. & No information found. \\
\hline $\begin{array}{l}\text { Oestlundia luteorosea } \\
\text { (A. Rich. \& Galeotti) } \\
\text { W. E. Higgins }\end{array}$ & $\begin{array}{l}\text { Epiphyte orchid of } 15-35 \mathrm{~cm} \\
\text { high, yellow green flowers } \\
\text { with purple spots, } \\
\text { inflorescence in panicle } \\
\text { laxiflora. } \\
\text { CITRO-UV. }\end{array}$ & $\begin{array}{l}\text { In the region of Zongolica, it is known as "topixcamote" } \\
\text { and it is used in traditional medicine to reduce or remove } \\
\text { pain in head bumps. The crushed pseudobulbs in alcohol or } \\
\text { "aguardiente" are applied as a poultice in the affected area. }\end{array}$ & No information found. & No information found. \\
\hline
\end{tabular}




\begin{tabular}{|c|c|c|c|c|}
\hline Orchid species & Botanical description/herbarium & Ethnobotany & Pharmacology & Active metabolites \\
\hline $\begin{array}{ll}\text { Oncidium ascendens } \\
\text { Lindl. }\end{array}$ & $\begin{array}{l}\text { Epiphyte orchid of } 10-30 \mathrm{~cm} \\
\text { high, with yellow green flowers } \\
\text { and red brownish spots in } \\
\text { paniculate florescences. } \\
\text { Herbarium XAL. }\end{array}$ & $\begin{array}{l}\text { Santos [22] mentions that it is known as "orquidea" by } \\
\text { settlers of Sierra de Santa Martha region in the } \\
\text { municipality of Soteapan, localities of Ejidos de Ocotal } \\
\text { Chico, Ocotal Grande, San Fernando y Santa Marta. Used } \\
\text { for infammation caused by introduction of sharp sticks or } \\
\text { tools. It is also used to carry out "limpias" (a kind of body } \\
\text { and soul cleaning by sweeping it externally with the plant). }\end{array}$ & $\begin{array}{l}\text { Biological activities, such as } \\
\text { inhibition of cancer cell lines } \\
\text { proliferation. Induction of } \\
\text { apoptosis [25]. }\end{array}$ & $\begin{array}{l}\text { Stilbenoids }[14] \text { and } \\
1, \quad \text { 4-Beta-mannan } \\
{[26] \text {. }}\end{array}$ \\
\hline $\begin{array}{l}\text { Scaphyglottis } \\
\text { fasciculata Hook. }\end{array}$ & $\begin{array}{l}\text { Epiphyte orchid of up to } 32 \mathrm{~cm} \\
\text { height, with white greenish } \\
\text { flowers in inflorescence in } \\
\text { fascicule. Herbaria CORU, } \\
\text { IMSSM. }\end{array}$ & $\begin{array}{l}\text { This species is known in Veracruz as "parásitamenuda", } \\
\text { "small parasite". Garrido [27] collected this plant in the } \\
\text { Tuxtlas region in the municipality of Catemaco in the } \\
\text { localities of Adolfo López Mateos, Benito Juárez, Dos } \\
\text { Amates, La Margarita, Miguel Hidalgo, San Rafael and the } \\
\text { colonies El Águila and Zapoapan de Cabañas. In this } \\
\text { region the medicinal use of this plant is indicated as } \\
\text { anti-abortive. }\end{array}$ & $\begin{array}{l}\text { Anti-inflammatory, } \\
\text { anti-nociceptive [28, 29] and } \\
\text { relaxing activities [30, 31] } \\
\text { detected in Scaphyglottis livida, a } \\
\text { close related species. }\end{array}$ & $\begin{array}{l}\text { Lanostadienol } \\
\text { derivative, gigantol, } \\
\text { ciclobalanone [29]. } \\
\text { Phenanthrenederivati } \\
\text { ve }[28,30] \text { and } 3,4- \\
\text { dihydroxi-5,5'-dimet } \\
\text { hoxy bibenzyl [30]. }\end{array}$ \\
\hline $\begin{array}{lll} & & \\
\text { Sobralia } & \text { macrantha } \\
\text { Lindl. } & & \\
& & \end{array}$ & $\begin{array}{l}\text { Terrestrial or epiphyte orchid of } \\
40-180 \mathrm{~cm} \text { height, with purple } \\
\text { flowers, white in their centers in } \\
\text { fascicular inflorescence. } \\
\text { Herbarium XAL. }\end{array}$ & $\begin{array}{l}\text { This orchid is known in Veracruz with the names of } \\
\text { "cabolín", "Candelaria" and "lirio de San Antonio". } \\
\text { Gutiérrez [32] describes that this species is found in the } \\
\text { region of the south of the sedimentary basin of Tampico } \\
\text { and Misantla in the municipality of Chiconquiaco, where it } \\
\text { is used for fever. }\end{array}$ & No information found. & No information found \\
\hline $\begin{array}{l}\text { Spiranthes } \\
\text { eriophora Rob. \& } \\
\text { Greenm. }\end{array}$ & $\begin{array}{l}\text { Terrestrial orchid of } 30-45 \mathrm{~cm} \\
\text { high, white flowers with yellow } \\
\text { center in rosette inflorescence. } \\
\text { Herbarium UACh. }\end{array}$ & $\begin{array}{l}\text { This species is known in Veracruz as "Cecetzi" y } \\
\text { "margaretilla". Sánchez [33] collected this orchid in the } \\
\text { Zongolica Sierra in the municipality of Tlaquilpa, localities } \\
\text { of Loma de Xocoapa, where it is used for the treatment of } \\
\text { asthma. }\end{array}$ & $\begin{array}{l}\text { An anti-oxidant activity has been } \\
\text { found in Spiranthes sinensis, a } \\
\text { related species [34]. }\end{array}$ & $\begin{array}{l}\text { The ethanoic extract } \\
\text { containing flavonoids } \\
\text { and ferulic acid [34]. }\end{array}$ \\
\hline $\begin{array}{ll} & \\
\text { Stanhopea oculata } & \mathrm{c} \\
\text { (G. Lodd.) Lindl. } & \mathrm{i} \\
& \mathrm{i}\end{array}$ & $\begin{array}{l}\text { Epiphyte orchid of } 30-50 \mathrm{~cm} \\
\text { height, with flowers pale yellow } \\
\text { orange color with purple spots } \\
\text { in raceme pendulum } \\
\text { inflorescence. Alive collection } \\
\text { in CITRO-UV Orchidarium. }\end{array}$ & $\begin{array}{l}\text { In Zongolica region, it is known as "Tehuanxochitl". The } \\
\text { crushed an boiled pseudobulbs are used to reduce abdomen } \\
\text { (belly) pain in women, by drinking the prepared infusion. }\end{array}$ & $\begin{array}{l}\text { It has been confirmed the } \\
\text { anti-fatigue activity in a related } \\
\text { species, Stanhopea hernandezii } \\
{[35] \text {. }}\end{array}$ & $\begin{array}{l}\text { Hexanic and } \\
\text { dichloromethane-met } \\
\text { hanol extract [35]. }\end{array}$ \\
\hline $\begin{array}{l}\text { Vanilla planifol } \\
\text { Andrews }\end{array}$ & $\begin{array}{l}\text { Hemiepiphyte climbing orchid } \\
\text { of up to } 12 \mathrm{~m} \text { height, with } \\
\text { flowers pale green to bright } \\
\text { white in axillary inflorescence. } \\
\text { Herbarium MEXU. }\end{array}$ & $\begin{array}{l}\text { This species is known in Veracruz as "vainilla" and it is } \\
\text { used as a flavour for cakes, drinks, chocolate and ice cream } \\
\text { preparations. Hernández [36] indicates the plant growth } \\
\text { and medicinal use of Vanilla in the municipality of } \\
\text { Misantla. It is used to treat grave fever, drinking the pods } \\
\text { infusion. }\end{array}$ & $\begin{array}{l}\text { Confirmed biological activities } \\
\text { include anti-oxidative, } \\
\text { anti-inflammatory, anti-cancer, } \\
\text { against cell stress [37-40], } \\
\text { anti-microbial [41], anti-cholesterol } \\
\text { [42], anti-nociceptive [43, 44], } \\
\text { anti-depressing and inhibition of } \\
\text { acetyl cholinesterase (Alzheimer) } \\
\text { [45]. }\end{array}$ & $\begin{array}{l}\text { Vanillin, } \\
\text { hydro-ethanolic } \\
\text { extract }[37,45] .\end{array}$ \\
\hline
\end{tabular}


of their habitats have led to these belated efforts to protect them.

As far as their ethnobotany, villagers use Epidendrum chlorocorymbos to relieve ear pain among other therapeutic applications in Veracruz. A similar traditional use to alleviate pain is referred to China for the stems of E. mosenii [20], a related species on which pharmacological testing proved a strong anti-nociceptive effect [18-20]. Laboratory tests demonstrated that a dichloromethane extract, 24-methylene-cicloartanol and phenanthrenes were responsible of this action [19-21]. No pharmacological or chemical research has been done on $E$. chlorocorymbos, but it is possible that this species might contain active phenanthrenes. Kovacs et al. [21] reported the presence of a number of these compounds in Orchidaceae, particularly in Epidendrum genus. In other states of Mexico, villagers use E. anisatum [46] and E. pastoris [47] to treat dysentery. Nepalese also use the last species [48], and the Chinese use E. tuberosum for the same purpose [49].

Patients ingest Habenaria floribunda leaves to stop vaginal hemorrhage in Veracruz. In China, tubers of $H$. repens are used as aphrodisiac and studies have confirmed anti-oxidant activity for this species due to habenariol [23]. Other Habenaria species from India are important in traditional medicine as restoratives and for blood diseases [50]. Researchers have yet to report any pharmacological studies on those species, however they might contain habenariol and could exert anti-oxidant activity, which would explain restoring vital functions of the body at a cell level and helping the patient to recover their health.

For Isochillus latibracteatus, I. major, Mormodes maculata var. unicolor and Oestlundia luteorosea medicinal species documented in this work, health problems underlying inflammation were registered. No information regarding other uses or biological activities was given elsewhere.

In China, for Oncidium ascendens, researchers have identified a similar traditional therapeutic application to the one documented in Veracruz, i.e., treating inflammation and lacerations of the body [49]. Although studies detected inhibition of cancer cell lines proliferation due to stilbenoids and $1,4-\beta$-mannan in this species $[25,26]$, this action does not explain the efficacy of its traditional therapeutic application.

The medicinal use of Scaphyglottis fasciculata as anti-abortive has been documented in Veracruz. The bibliographical research revealed neither other medicinal uses nor genus related medicinal species. Nevertheless, the proven pharmacological effects in a related species, S. livida, include anti-inflammatory [28], anti-nociceptive [29] and smooth muscle relaxing activity $[30,31]$. The responsible compounds were a lanostadienol derivative, gigantol, ciclobalanone [29], phenanthrene derivatives [28, 30] and 3,4-dihydroxi-5,5'-dimetoxy benzyl [30]. The above activities, confirmed through pharmacological testing, might have an overall positive effect that could be related to the therapeutic application of $S$. fasciculate as anti-abortive, but it is necessary to carry out pharmacological research to prove it.

Sobralia macrantha is another medicinal orchid documented for Veracruz to be used to treat fever cases. A similar application is given to the macerated leaves mixed with orange juice in other regions of Mexico [47]. Nevertheless, no other information for this species was encountered.

The medicinal use of Spiranthes eriophora for asthma in Veracruz was not found anywhere else, but other studies demonstrated an anti-oxidant activity for S. sinensis a related species [34]. The ethanolic extract containing flavonoids and ferulic acid were responsible for this action [34]; new isopentenyl dihydrophenanthrenes were isolated from this species too, with possible additional biological effects [48]. $S$. sinensis therapeutic applications in Nepal include for fever, as a tonic, in sores [4], and in China and Taiwan as an aphrodisiac, for headache, chronic dysentery and meningitis [49]. An anti-cancer dihydroflavanoid was 
isolated from Spiranthes australis [50] used in Trinidad and Tobago, and in China for urinary problems, diabetes, treatment of inflammatory diseases and cancer [50, 51]. Pharmacological and chemical findings in S. sinensis and S. australis suggest S. eriophora might contain active metabolites too.

With Stanhopea oculata abdomen pain is treated in Veracruz, but no other record of medicinal use was found. A related species, $S$. hernandezii, is recommended against tiredness in other regions of Mexico [47]. The anti-fatigue activity was confirmed for this species with hexane and dichloromethane-methanol extracts through pharmacological testing. Apparently, there is no relation between these findings and the therapeutic application of S. oculata.

Although Vanilla planifolia is one of the most important orchids in the world because of the aromatic and flavoring properties of their fermented pods, the medicinal use has faded over the centuries in Mexico. It is native to Mexico and is grown commercially in Veracruz on a small scale. But in contrast with around 12 different therapeutic applications given to this plant in the 16th century $[11,52]$, today just two are indicated for grave fever and abdomen pain [12]. Confirmed biological activities include anti-oxidant, anti-inflammatory, anti-cancer, against cell stress [37-40], anti-microbial [41], anti-cholesterol [42], anti-nociceptive [43, 44], anti-depressant and inhibitory of acetylcholinesterase (Alzheimer) [45]. Mainly vanillin is the responsible active metabolite [37-45]. Pharmacological effects demonstrated in $V$. planifolia give evidence of its efficacy, if the fever is the result of any kind of bacterial infection. The anti-oxidant, anti-cell stress and anti-nociceptive effects will help patients with fever. Therefore, Vanilla is an orchid with a great potential in modern medicine and cultivation should be promoted.

\section{Conclusions}

This paper demonstrates the lack of studies on ethnobotanical, pharmacological and chemical aspects of medicinal orchids from the state of Veracruz and shows the need to carry out research on those subjects to increase their knowledge. It also demonstrates that Vanilla planifolia is a very important orchid with great potential in modern medicine, so its cultivation should be promoted. It becomes necessary to perform conservation studies in order to implement programs for the protection and propagation of endangered species, like Mormodes maculate, Stanhopea oculata and Vanilla planifolia.

\section{Acknowledgments}

The authors thank their colleagues Daniel Cornu for Habenaria floribunda and Isochillus latibracteatus and David Jimeno for Isochillus major and Oncidium ascendens photographies. Spiranthes eriophora was photographed by Carlos Velazco.

\section{References}

[1] Dressler, R. L. 2005. "How Many Orchid Species?" Selbyana 26 (1-2): 155-8.

[2] Hossain, M. M. 2011. "Therapeutic Orchids: Traditional Uses and Recent Advances: An Overview." Fitoterapia 82 (2): 102-40.

[3] Cox, L. D. 2013. "Orchids: Importance and Use in Mexico.” Bioagrociencias 6 (2): 4-7. (in Spanish)

[4] Soto, A. M. A., Hágsater, E., Jiménez, R., Salazar, G. A., Solano, R., Flores, R., and Ruiz, I. 2007. Orchids of Mexico: Digital Catalogue. Mexico, D.F.: Instituto Chinoin.

[5] Castañeda-Zarate, M., Vicon-Esquivel, J., Ramos-Castro, S. E., and Solano-Gómez, R. 2011. "New Records of Orchidaceae for Veracruz, Mexico." Rev. Mex. Biodiv. 83: 281-4. (in Spanish)

[6] Misra, S. 2004. Orchids of Orissa. Dehradun, India: Bishen Singh Mahendra Pal Singh Publisher.

[7] Dash, P. K., Sahoo, S., and Bal, S. 2008. "Ethnobotanical Studies on Orchids of Niyamgiri Hill Ranges, Orissa, India.” Ethnobotanical Leaflets 12: 70-8.

[8] Kong, J. M., Goh, N. K., Chia, L. S., and Chia, T. F. 2003. "Recent Advances in Traditional Plant Drugs and Orchids." Acta Pharmacol. Sin. 24 (1): 7-21.

[9] Kumari, H., Pushpan, R., and Nishteswar, K. 2012. "Multi Faceted Actions of Orchids in Ethno Medicine-An Appraisal." International Journal of Pharmaceutical \& Biological Archives 3 (4): 996-1002. 
[10] Pant, B. 2013. "Medicinal Orchids and Their Uses: Tissue Culture a Potential Alternative for Conservation." African Journal of Plant Science 7 (10): 448-67.

[11] De la Cruz, M. 1964. Libellus de Medicinalibus Indorum Herbis, 1st ed.. Mexico, D. F.: Mexican Institute of Social Security (IMSS). (in Spanish)

[12] Argueta, V. A., and Cano, A. L. M. 1994. Plant Atlas of the Mexican Traditional Medicine. México, D. F.: Indians National Institute. (in Spanish)

[13] Garcia, G. C., Gomez, R. S., and Rivera, L. L. 2014. "Documentation of the Medicinal Knowledge of Prosthechea karwinskii in a Mixtec Community in Mexico." Revista Brasileira de Farmacognosia 24 (2): 153-8.

[14] Cano-Asseleih, L. M. 1997. Veracruz Medicinal Flora: Part I, Ethnobotanical Inventory, 1st ed.. Xalapa, Veracruz: Veracruz University. (in Spanish)

[15] Hammer, F. 2009. "Orchidaceae: Flora of Nicaragua." Tropicos Missouri Botanical Garden. Accessed September 10, 2015. http://www.tropicos.org/Name/42000388.

[16] Mexican Environment and Natural Resources Secretary. Federal Official Newspaper 2nd Section: Mexican Official Regulation NOM-059-SEMARNAT 2010. (in Spanish)

[17] Burgos, H. M. 2009. "Vascular Flora with Potential Charcteristics for the Use and Conservation of Forest Fragments in Atzalan Municipality, Veracruz." Master thesis, Ecology Institute A. C., Xalapa, Veracruz. (in Spanish)

[18] Rosa, P. W., Machado, M. S., Campos-Buzzi, F., Niero, R., Delle-Monach, F., and Cechinel-Filho, V. 2007. "Seasonal and Biological Variations of Epidendrum mosenii: Quantification of 24-Methylenecycloartanol Using Gas Chromatography." Nat. Prod. Res. 21 (11): 975-81.

[19] Ferreira, J., Floriani, A. E., Filho, V. C., Delle-Monach, F., Yunes, R. A., Calixto, X. B., and Santos, A. R. 2000. "Anti-nociceptive Properties of the Methanolic Extract and Two Triterpens Isolated from Epidendrum mosenii Stems (Orchidaceae)." Life Sci. 66 (9): 791-802.

[20] Floriani, A. E., Ferreira, J., Santos, A. R., Delle-Monache, F., Yunes, R. A., and Cechinel-Filho, V. 1998. "Analgesic Compounds from Epidendrum mosenii Stems." Pharmazie 53 (6): 426-7.

[21] Kovacks, A., Vasas, A., and Hohmann, J. 2008. "Natural Phenanthrenes and Their Biological Activity." Phytochemistry 69 (5): 1084-110.

[22] Santos, R. M. A. 1988. "Ethnobotany: Medicinal Plants of Zoque-Popolucas of Ejidos of San Fernando, Santa Marta, Ocotal Grande and Ocotal Chico, Soteapan, Municipality, Veracruz." Bachelor thesis, Biology Faculty, Veracruz University, Xalapa, Veracruz. (in Spanish)

[23] Johnson, M. K., Alexander, K. E., Lindquist, N., and Loo,
G. 1999. "A Phenolic Anti-oxidant from the Freshwater Orchid, Habenaria repens." Comp. Biochem. Physiol. Part C: Pharmacology, Toxicology and Endocrinology 122 (2): 211-4

[24] Hernández, A. M. E. 2006. "Medicinal Plants of Four Localities from the Municipality of Ixtaczoquitlan, Veracruz." Bachelor thesis, Facultad de Ciencias Biologicas y Agropecuarias, Universidad Veracruzana, Cordoba, Veracruz.

[25] Williams, R. B., Martin, S. M., Hu, J. F., Garo, E., Rice, S. M., Norman, V. L., Lawrence, J. A., Hough, G. W., Goering, M. G., O’Neil-Johnson, M., Eldridge, G. R., and Starks, C. M. 2012. "Isolation of Apoptosis-Inducing Stilbenoids from Four Members of Orchidaceae Family." Planta Med. 78 (2): 160-5.

[26] Wang, H. L., Yen, K. W., Chen, P. R., Chang, C. H., Chen, J. M., and Khoo, K. H. 2006. "Isolation and Characterization of a Pure Mannan from Oncidium (cv. Gower Ramsey) Current Pseudobulb during Initial Inflorescence Development." Biosci. Biotechnol. Biochem. 70 (2): 551-3.

[27] Garrido, V. A. 1997. "Ethnography and Analysis of Plants Use from Eight Mestizo Communities from the Municipality of Catemaco, Veracruz." Bachelor thesis, Facultad de Ciencias Biológicas y Agropecuarias. Universidad Veracruzana, Cordoba, Veracruz.

[28] Déciga-Campos, M., Gonzales-Trujano, E., Navarrete, A., and Mata, R. 2005. "Anti-nociceptive Effect of Selected Mexican Tradicional Medicinal Species." Proc. West. Pharmacol. Soc. 48: 70-2.

[29] Déciga-Campos, M., Palacios-Espinosa, J. F., Reye-Ramírez, A., and Mata, R. 2007. "Anti-nociceptive and Anti-inflammatory Effects of Compounds Isolated from Scaphyglottis livida and Maxilaria densa." J. Ethnopharmacol. 114 (2): 161-8.

[30] Estrada, S., Rojas, A., Mathison, Y., Israel, A., and Mata, R. 1999. "Nitric Oxide/cGMP Mediates the Spasmolytic Action of 3, 4'-Dihydroxy-5, 5'-Dimethoxybibenzyl from Scaphyglottis livida." Planta Med. 65 (2): 109-14.

[31] Estrada-Soto, S., López-Guerrero, J. J., Villalobos-Molina, R., and Mata, R. 2006 "Endothelium-Independent Relaxation of Aorta Rings by Two Stilbenoids from the Orchid Scaphyglottis livida." Fitoterapia 77 (3): 236-9.

[32] Celso, G. B. 1995. "Useful Plantas from Chiconquiaco, Veracruz." La Ciencia y el Hombre 19: 65-75.

[33] Sánchez, R. P., Camila, S. C., Agustina, D. O., and Erick, C. P. 2003. Medicinal Plants Catalogue of Tlaquilpa and Astacinga, Veracruz. Mexico: Chapingo Autonomous University. (in Spanish)

[34] Liang, C. P., Chang, C. H., Liang, C. C., Hung, K. Y., and Hsieh, C. W. 2014. "In Vitro Anti-oxidant Activities, 
Free Radical Scavenging Capacity and Tyrosinase Inhibitory of Flavonoid Compounds and Ferulic Acid from Spiranthes sinensis (Pers.) Ames." Molecules 19 (4): 4681-94.

[35] Enciso, D. O. J., Perea, A. I., and Castillo, E. P. 2015. "Pharmacological Preliminary Evaluation of Pseudobulb and Root Extracts of Stanhopea hernandezii." In Proceedings of the First International Tropical Orchids Congress, 67-8.

[36] Hernández, L. J. A. 1988. "Study on Herbals and Traditional Medicine of Misantla Municipality, Veracruz." Bachelor thesis, Sciences Faculty, National Autonomous University of Mexico (UNAM), México, D. F. (in Spanish)

[37] Khuda-Bukhsh, A. R., Das, S., and Saha, S. K. 2014. "Molecular Approaches toward Targeted Cancer Prevention with Some Food Plants and Their Products: Inflammatory and Other Signal Pathways.” Nutr. Cancer 66 (2): 194-205.

[38] Kapoor, S. 2013. "Multiorgan Anti-carcinogenic Effects of Vanillin.” J. Med. Food 16 (9): 777.

[39] Ho, K., Yazan, L. S., Ismail, N., and Ismail, M. 2009. "Apoptosis and Cell Cycle Arrest of Human Colorectal Cancer Cell Line HT-29 Induced by Vanillin." Cancer Epidemiol. 33 (2): 155-60.

[40] Makni, M., Chtourou, Y., Fetoui, H., El-Mouldi, G., Bowdawara, T., and Zeghal, N. 2011. "Evaluation of the Anti-oxidant, Anti-inflammatory and Hepatoprotective Properties of Vanillin in Carbon Tetrachloride-Treated Rats.” Eur. J. Pharmacol. 668 (1-2): 133-9.

[41] Fitzgerald, D. J., Stratforf, M., Gasson, M. J., Ueckert, J., Bos, A., and Narbad, A. 2004. "Mode of Anti-microbial Action of Vanillin against Escherichia coli, Lactobacillus plantarum and Listeria innocua." J. Appl. Microbiol. 97 (1): 104-13.

[42] Srinivasan, M. R., and Chandrasekhara, N. 1992. "Comparative Influence of Vanillin \& Capsaicin on Liver and Blood Lipids in the Rat." Indian J. Med. Res. 96: 133-5.
[43] Shoeb, A., Chowta, M., Pallempati, G., Rai, A., and Singh, A. 2013. "Evaluation of Anti-depressant Activity of Vanillin in Mice.” Indian J. Pharmacol. 45 (2): 141-4.

[44] Park, S. H., Sim, Y. B., Choi, S. M., Seo, Y. J., Kwon, M. S., Lee, J. K., and Suh, H. W. 2009. "Anti-nociceptive Profiles and Mechanisms of Orally Administered Vanillin in the Mice." Arch. Pharm. Res. 32 (11): 1643-9.

[45] Kundu, A., and Mitra, A. 2013. "Flavouring Extracts of Hemisdesmus indicus Roots and Vanilla planifolia Pods Exhibit in Vitro Acetylcholinesterase Inhibitory Activities." Plant Foods Hum. Nutr. 68 (3): 247-53.

[46] Hágsater, E., Soto, A. M. A., Salazar, C. R., Jiménez, M. R., López, R. M. A., and Dressler, R. L. 2005. Orchids from Mexico. Mexico, D. F.: Instituto Chinoin, 304.

[47] García, P. M., and Peña, M. 1981. "Use of Orchids in Mexico since Prehispanic Times to Our Days." Orquídea 8 (1): 56-74. (in Spanish)

[48] Tezuka, Y., Li, J., Hirano, H., Ueda, M., Nagashima, K., and Kikuchi, T. 1990. "Studies on the Constituents of Orchidaceous Plants IX-Constituents of Spiranthes sinensi (Pers.) Ames var. Amoena (M. Bieberson) Hara: Part 2, Structures of Spiranthesol, Spiranthoquinona, Spiranthol-C and Spirasineol-B, New Isopentenyldihydrophenantrenes." Chem. Pharm. Bull. 38 (3): 629-35.

[49] Lin, Y. L., Huang, R. L., Don, M. J., and Kuo, Y. H. 2000. "Dihydrophenanthrenes from Spiranthes sinensis." J. Nat. Prod. 63 (12): 1608-10.

[50] Lans, C., Harper, T., Georges, K., and Bridgewater, E. 2001. "Medicinal and Ethnoveterinary Remedies of Hunters in Trinidad." BMC Complementary and Alternative Medicine 1: 10-5.

[51] Peng, J. Y., Xu, Q. W., Xu, Y. W., Qi, Y., Han, X., and Xu, L. N. 2007. "A New Anti-cancer Dihydroflavanoid from the Root of Spiranthes australis (R. Brown) Lindl.." Nat. Prod. Res. 21 (7): 641-5.

[52] Hernández, F. 1959. Natural History of New Spain. México: National Autonomous University of Mexico (UNAM). (in Spanish) 